\title{
Estimasi Volume Buah Kiwi Menggunakan Metode Pencitraan dan Aturan Simpson
}

\author{
Tomy Suherly, Minarni Shiddiq* \\ Program Studi Fisika, Universitas Riau, Pekanbaru, Indonesia \\ Email: thommyt433@gmail.com,*minarni@unri.ac.id
}

\begin{abstract}
Abstrak-Volume merupakan salah satu besaran penting yang telah digunakan untuk penyortiran buah berdasarkan ukuran Metode pencitraan atau Computer Vision adalah metode nondestruktif sederhana yang telah diusulkan untuk menentukan volume buah. Penelitian ini bertujuan untuk mengestimasi volume buah kiwi menggunakan metode pencitraan Computer Vision dan dibandingkan dengan metode perpindahan air. Sampel yang digunakan adalah 20 buah kiwi hijau (Actinidia deliciosa). Kamera smartphone digunakan untuk merekam citra dan perangkat lunak berbasis Python digunakan untuk pengendali kamera dan pengolah citra. Citra hasil Computer Vision adalah citra dua dimensi (2D). Citra 2D ini diolah dengan Aturan Simpson 1/3 untuk menentukan volume buah kiwi berdasarkan prinsip integrasi volume benda putar dimana citra permukaan 2D buah kiwi dicacah menjadi 8 bagian kemudian dijumlahkan. Hasil penelitian menunjukkan bahwa metode pencitraan dengan bantuan aturan Simpson 1/3 berhasil digunakan untuk menentukan volume buah kiwi dengan persentase perbedaan rata rata sebesar 4,57 \% dibanding pengukuran menggunakan metode perpindahan air, ini setara dengan perbedaan volume rata-rata sebesar $4,97 \mathrm{~cm}^{3}$ dari 20 sampel. Volume buah kiwi yang diukur dengan metode ini berkisar antara $82,48 \mathrm{~cm}^{3}-126,85 \mathrm{~cm}^{3}$. Hasil ini merupakan langkah awal dari pengembangan machine vision untuk penyortiran buah berdasarkan volume.
\end{abstract}

Kata Kunci: Computer Vision, Aturan Simpson, Volume, Buah Kiwi, Python

\begin{abstract}
Volume is one of important quantities that have been applied to fruit sorting based on size. Imaging method or computer vision is a simple non destructive method that has been proposed to measure fruits volume. This study was aimed to estimate the volumes of kiwi fruits using Computer Vision imaging method and compared to a water displacement method. The samples were 20 green kiwi fruits (Actinidia deliciosa). A smartphone camera was used to record the kiwifruit images and Python based program to drive the camera and process the images. Images resulted in Computer Vision are two dimensions (2D) images. The 1/3 rd Simpson rule was employed to determine the volume of kiwi fruits based on the volume integration of a spinning object where surface image of kiwi was divided into 8 parts and then summed. The results show that the 2D imaging method assisted by the Simpson rule was successfully able to determine the kiwi fruit volumes with $4.57 \%$ average difference percentage compared to the water displacement method. This was about $4.97 \mathrm{~cm}^{3}$ of average volume difference of 20 samples. The sample volumes measured using this method ranges from $82,48 \mathrm{~cm}^{3}-126,85 \mathrm{~cm}^{3}$. These results will be one of steps toward the development of machine vision for fruit sorter based on volume.
\end{abstract}

Keywords: Computer Vision, 1/3 rd Simpson Rule, Volume, Kiwi Fruit, Python

\section{PENDAHULUAN}

Metode pencitraan adalah metode optik yang semakin intensif digunakan dalam berbagai bidang karena bersifat nondestruktif, cepat, dan dapat diandalkan. Metode pencitraan bersifat nosdestruktif karena tidak terjadi kontak fisik secara langsung dengan objek. Metode pencitraan yang telah dikembangkan saat ini adalah metode pencitraan untuk medis seperti MRI, CT scan, dan metode Computer Vision. Metode Computer Vision mengunakan kamera, cahaya dan komputer. Metode ini terdiri dari beberapa jenis bergantung pada komponen sistem dan tujuan aplikasinya. Metode Computer Vision tradisional adalah metode pencitraan mengunakan kamera warna atau monokrom yang menghasilkan citra dua dimensi (2D). Metode ini dapat digunakan untuk menganalisa karakteristik ekternal objek seperti ukuran, bentuk, warna, dan tekstur [1]. Metode pencitraan 2D dapat dikembangkan menjadi pencitraan tiga dimensi (3D) mengunakan bantuan berkas cahaya terstruktur atau kamera stereo untuk menentukan volume atau bentuk 3D objek [2]. Metode pencitran spektral seperti pencitraan fluoresensi, hiperspektral, dan multispektral.adalah gabungan antara metode Computer Vision 2D dan spektroskopi yang bergantung pada panjang gelombang cahaya sebelum dan setelah mengenai objek. Metode ini dikembangkan untuk menganalisa karakteristik internal objek seperti sifat kimia dan fisika produk pertanian [3]. Kamera pada umumnya dihubungkan ke komputer untuk memudahkan dan mempercepat dalam pengolahan citra. Saat ini dengan perkembangan teknologi di bidang komputer, perangkat lunak, kamera dan sumber cahaya, sistem Computer Vision dapat dibangun lebih ekonomis dan reliable.

Pada dua dekade terakhir, metode pencitraan Computer Vision telah dikembangkan secara intensif pada bidang pertanian. Metode pencitraan dapat memberikan informasi berupa karakteristik produk pertanian melalui analisis citra. Teknologi Computer Vision memiliki sifat yang cepat, ekonomis, konsisten dan objektif sehingga dapat digunakan untuk membantu proses penyortiran dan penentuan kualitas objek yang masih tradisional dan manual [4], khususnya pada bidang pertanian yang masih mengunakan tenaga manusia dengan mengandalkan pengalaman, keahlian, dan panca indera. Metode Computer Vision merupakan sistem berbasis algoritma dan komputer yang menirukan mata manusia untuk mendeskripsikan citra dari suatu objek. Teknologi Computer Vision telah dikembangkan dan diaplikasikan untuk berbagai keperluan di bidang makanan dan pertanian seperti pencitraan berbasis smartphone untuk diagnostik makanan [5], alat 
pendeteksi kematangan buah apel menggunakan metode pencitraan berdasarkan komposisi warna. [6], menghitung geometri telur mengunakan machine vision [7], mengestimasi massa buah mangga secara geometri mengunakan pengolahan citra [8]. Machine vision merupakan suatu sistem yang lengkap dimana computer vision merupakan salah satu bagian untuk mengambil keputusan berdasarkan citra yang diperoleh.

Volume adalah ukuran benda yang dapat digunakan sebagai besaran fisika untuk penyortiran buah. Penyortiran sangat penting dilakukan untuk pengelompokan dan penentuan mutu suatu produk pertanian. Disamping massa, penyortiran produk pertanian berdasarkan volume sangat diperlukan di bidang industri pertanian, volume berhubungan dengan rasa buah dan jumlah kandungan gula [9]. Volume dan massa buah dapat diestimasi mengunakan pengolahan citra mengunakan dua kamera. Volume dan massa mempunyai korelasi yang tinggi [10].

Computer Vision dapat digunakan untuk menentukan volume atau luas suatu benda dengan bantuan algoritma seperti Aturan Simpson atau metode trapesium [11]. Metode ini telah digunakan untuk menentukan volume telur menggunakan jaringan syaraf tiruan (ANN) [12]. Metode aturan Simpson merupakan salah satu metode numerik yang dapat digunakan menentukan volume suatu benda. Penentuan volume benda dengan bantuan aturan ini telah berhasil digunakan untuk penentuan volume lambung kapal [13].

Buah kiwi adalah salah satu jenis buah yang menyumbang kenaikan persentase buah impor di Indonesia. Ini disebabkan karena buah kiwi mengandung nutrisi yang cukup besar dibanding buah-buah impor dan lokal. Menjaga kualitas dan mutu buah kiwi perlu dilakukan setelah menempuh perjalanan yang cukup lama dari negara pengekspor. Proses sortasi yang cepat dan ekonomis merupakan salah satu cara untuk menjaga kualitas buah-buahan impor salah satunya adalah buah kiwi. Buah kiwi memiliki kulit berwarna hijau gelap kecoklatan dengan struktur daging buah berwarna hijau terang atau kuning emas dan biji berwarna hitam yang dapat dimakan [14]. Buah kiwi mengandung vitamin E, Vitamin C, Anti oksidan, serta kandungan mineral seperti kalium, magnesium, kalium, dan jenis mineral lainnya [15].

Metode Computer Vision dapat digunakan dalam proses sortasi buah kiwii. Parameter fisika buah kiwi seperti panjang, lebar, ketebalan, massa, volume (true dan apparent) dapat digunakan sebagai parameter sortasi [16]. Buah kiwi pada umumnya memiliki bentuk geometri elipsoida sehingga volumenya dapat ditentukan mengunakan volume elpsoida. Volume buah kiwi juga dapat ditentukan mengunakan pengolahan citra 2D. Metode perpindahan air digunakan sebagai acuan untuk menentukan volume buah kiwi, volume buah kiwi yang telah diukur berkisar antara 54,7-108,2 $\mathrm{cm}^{3}$ [17]. Pengunaan metode pencitraan atau Computer vision juga telah dilakukan untuk buah kiwi untuk klasifikasi mengunakan bentuk [18] dan penyortiran buah kiwi mengunakan volume melalui rekonstruksi 3D dari citra 2D [19].

Pada penelitian ini, metode Computer Vision digunakan untuk menentukan volume buah kiwi. Algoritma aturan Simpson 1/3 berdasarkan prinsip integrasi volume benda putar digunakan dalam estimasi volume buah tersebut. Sampel yang digunakan berjumlah 20 buah kiwi (Actinidia deliciosa) dengan ukuran yang hampir sama. Kamera smartphone digunakan untuk merekam citra buah kiwi. Perangkat lunak pengendali kamera dan pengolahan citra dirancang dan dibuat mengunakan bahasa pemrograman Python. Hasil estimasi volume buah kiwi mengunakan metode ini dibandingkan dengan hasil yang diperoleh mengunakan metode perpindahaan air. Analisis regresi dari kedua metode dan hasil plot Bland-Altman dibahas.

\section{METODOLOGI PENELITIAN}

Penelitian ini mengunakan metode ekperimen yang bertujuan untuk mengestimasi volume buah kiwi menggunakan metode Computer Vision dan Algoritma aturan Simpson 1/3. Metode Computer Vision digunakan sebagai metode pengolahan citra sedangkan algoritma aturan Simpson 1/3 digunakan sebagai metode numerik untuk menentukan volume buah kiwi berdasarkan prinsip integrasi volume benda putar. Pendekatan volume yang digunakan adalah pendekatan elipsoida [17]. Metode ini mengunakan sistem yang sederhana yaitu kamera, komputer, namun membutuhkan desain algoritma yang tepat agar proses estimasi berjalan dengan cepat dan tepat. Metode perpindahan air digunakan sebagai pembanding keakuratan nilai volume yang diperolah menggunakan metode Computer Vision danalgoritma aturan Simpson 1/3.

Bahan dan alat yang digunakan adalah sampel buah kiwi, komponen optik dan penyangga untuk membangun sistem Computer Vision, serta komputer dan perangkat lunak untuk menyimpan dan mengolah citra. Sampel buah kiwi terdiri dari 20 buah dengan ukuran yang hampir sama besar di beri label dari KH1 sampai KH20. Alat yang digunakan adalah meja optik, meteran ukur, penyangga kamera, kamera smartphone, holder hp U, laptop, app IP webcam, sublime text dan software Python 3.7.4. Kamera yang digunakan mempunyai resolusi $13 \mathrm{MP}(\mathrm{f} / 2.0)+2 \mathrm{MP}$ (depth). Peralatan lainnya yang digunakan adalah gelas beker dengan skala ukur 0-1000 mililiter untuk menentukan volume buah kiwi menggunakan metode perpindahan air, volume diukur berdasarkan perpindahan permukaan air sebelum dan sesudah dimasukkan buah kiwi.

Penentuan volume buah kiwi menggunakan metode Computer Vision dan algoritma aturan Simpson 1/3 dilakukan melalui langkah-langkah yang berurutan. Langkah-langkah tersebut antara lain adalah persiapan alat dan sampel, menyusun sistem Computer Vision, selanjutnya melakukan perekaman citra permukaan buah kiwi, 
JURNAL MEDIA INFORMATIKA BUDIDARMA

Volume 4, Nomor 3, Juli 2020, Page 535-543

ISSN 2614-5278 (media cetak), ISSN 2548-8368 (media online)

Available Online at https://ejurnal.stmik-budidarma.ac.id/index.php/mib

DOI 10.30865/mib.v4i3.2144

menentukan volume buah kiwi mengunakan metode perpindahan air, melakukan kalibrasi pixel ke $\mathrm{cm}$ untuk menentukan panjang sumbu mayor dan minor, kemudian setelah panjang sumbu mayor dan minor diperoleh volume buah kiwi dapat ditentukan menggunakan algoritma aturan Simpson 1/3 berdasarkan prinsip integrasi volume benda putar.

\subsection{Perekaman Citra}

Skema sistem Computer Vision untuk perekaman citra dapat dilihat pada Gambar 1. Metode perpindahan air dan pengukuran dimensi buah secara manual mengunakan meteran digunakan sebagai pembanding. Kamera berfungsi untuk merekam citra dari permukaan sampel buah kiwi yang terhubung ke komputer melalui app IP webcam. Jarak kamera dan permukaan buah kiwi diatur sebesar $13 \mathrm{~cm}$ (working distance) agar kamera dapat menangkap keseluruhan permukaan sampel buah kiwi. Perekaman dilakukan meggunakan latar belakang berwarna putih. Perekaman citra dilakukan satu kali untuk setiap sampel. Disamping perekaman citra, untuk setiap sampel panjang buah, diameter mayor dan minor diukur mengunakan jangka sorong digital. Selanjutnya pengukuran volume buah kiwi mengunakan metode perpindahan air dilakukan. Pengukuran secara manual dan dengan perpindahan air dilakukan 2 kali untuk setiap sampel buah kiwi.

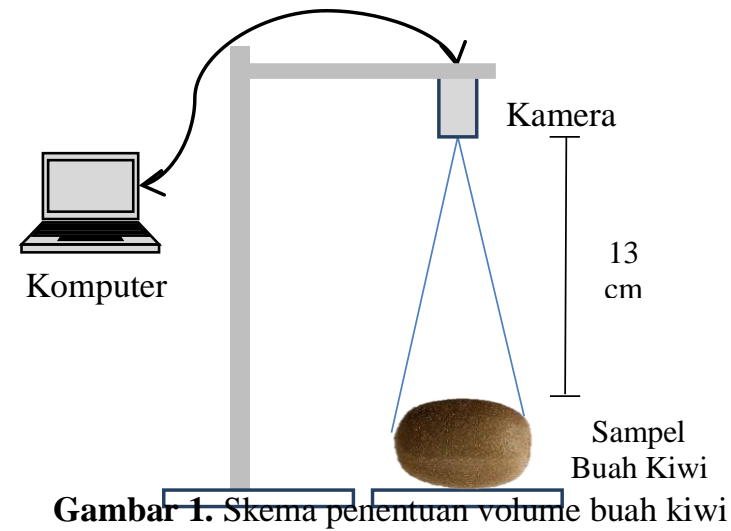

\subsection{Konversi pixel ke cm}

Langkah selanjutnya dalam estimasi volume buah kiwi setelah citra 2D buah kiwi diperoleh dan pengkuran volume mengunakan metode perpindahan air dilakukan adalah menentukan jumlah pixel pada sumbu mayor dan minor dari citra buah kiwi [17]. Penentuan jumlah pixel dilakukan menggunakan Matplotlib. Matplotlib adalah salah satu library dari program Python yang berfungsi untuk melakukan plot citra 2D. Setelah jumlah pixel pada sumbu mayor dan minor diperoleh, konversi nilai pixel ke satuan panjang sentimeter dilakukan. Untuk mengetahui jumlah pixel dalam satu sentimeter, proses yang harus dilakukan adalah merekam citra permukaan buah kiwi dan mistar yang berada di permukaan sampel buah kiwi seperti yang terlihat pada Gambar 2. Jumlah pixel dalam satu sentimeter dijadikan referensi dalam mengkonversi nilai pixel ke sentimeter untuk menghitung panjang sumbu mayor dan sumbu minor dari citra yang direkam. Kemudian data tersebut digunakan untuk menentukan volume buah kiwi menggunakan algoritma aturan Simpson 1/3. Dari proses penentuan jumlah pixel seperti yang terlihat pada Gambar 2 diperoleh 393,94 pixel dalam rentang panjang satu sentimeter, sehingga dalam menentukan panjang sumbu mayor dan sumbu minor pada citra permukaan buah kiwi yang telah direkam dapat ditentukan mengunakan Persamaan 1.

$$
\text { Panjang }(\mathrm{cm})=\frac{\text { Jumlah piksel pada citra }(\text { piksel })}{393,94\left(\frac{\text { piksel }}{\mathrm{cm}}\right)}
$$




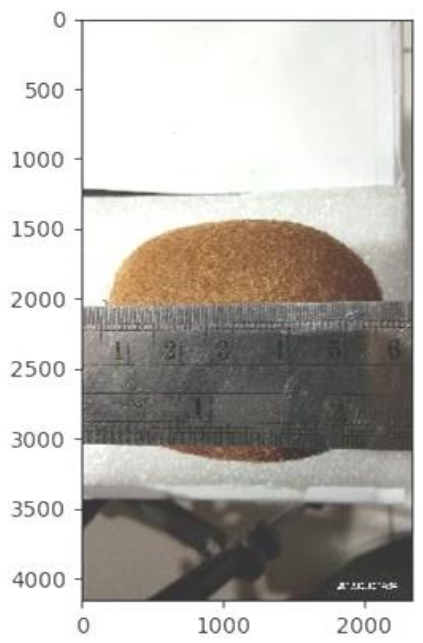

Gambar 2. Kalibrasi jumlah piksel ke centimeter

\subsection{Penentuan Volume Buah Kiwi}

Penentuan volume buah kiwi menggunakan metode aturan Simpson 1/3 dilakukan dengan mencacah citra 2D dari permukaan buah kiwi yang diperoleh dari hasil tangkap kamera menggunakan sistem Computer Vision seperti yang terlihat pada Gambar 1. Pencacahan citra 2D permukaan buah kiwi bertujuan untuk membagi citra tersebut menjadi beberapa bagian. Pada penelitian ini, citra 2D permukaan buah kiwi dibagi menjadi delapan bagian (aturan Simpson 1/3) seperti yang terlihat pada Gambar 3. Tiap-tiap bagian memiliki lebar segmen yang sama yang disimbolkan dengan huruf $h$. Lebar dari tiap segmen dapat dihitung menggunakan Persamaan 2. Panjang sumbu mayor dihitung dari titik $\mathrm{a}=\mathrm{x}_{1} \mathrm{ke}$ titik $\mathrm{b}=\mathrm{x}_{9}$ dan panjang sumbu minor dihitung sepanjang $\Delta \mathrm{y}$ dimana $\Delta y / 2=c$.

$$
h=\frac{b-a}{n}
$$

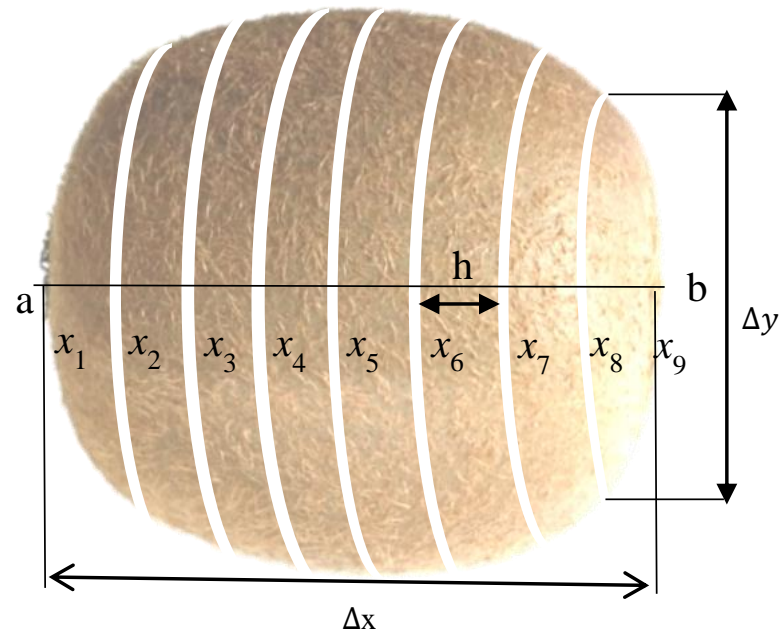

Gambar 3. Bagian-bagian cacahan citra 2D permukaan buah kiwi.

Algoritma penentuan volume menggunakan metode aturan Simpson 1/3 berdasarkan prinsip integrasi volume benda putar dapat dilihat pada Gambar 4. Pemrograman Python digunakan untuk mendapatkan nilai volume buah kiwi. Sublime text adalah text editor yang digunakan untuk menyusun dan memodifikasi algoritma pemrograman.Untuk mendapatkan nilai volume dari sampel buah kiwi, langkah diawali dengan input citra 2D dari permukaan buah kiwi yang diperoleh dari hasil perekaman oleh kamera yang disimpan dalam format JPEG. Kemudian dilakukan proses kalibrasi citra dengan tujuan untuk mengkonversi nilai pixel dalam satuan sentimeter. Pendekatan bentuk geometri ellips merupakan pendekatan bentuk yang digunakan dari citra 2D 


\section{JURNAL MEDIA INFORMATIKA BUDIDARMA}

Volume 4, Nomor 3, Juli 2020, Page 535-543

ISSN 2614-5278 (media cetak), ISSN 2548-8368 (media online)

Available Online at https://ejurnal.stmik-budidarma.ac.id/index.php/mib DOI 10.30865/mib.v4i3.2144

permukaan buah kiwi, sehingga konversi nilai pixel dalam satuan sentimeter bertujuan untuk mendapatkan panjang sumbu mayor dan sumbu minor. Dari informasi ini, nilai parameter a, b dan c dapat ditentukan. Kemudian langkah berikutnya adalah menentukan jumlah segmen pembagi permukaan citra 2D buah. Volume dari masing-masing segmen ditentukan dengan metode aturan Simpson 1/3 berdasarkan prinsip integrasi volume benda putar menggunakan Persamaan (5) [12] yang diturunkan dari Persamaan (3) dan Persamaan (4) [17]. Volume buah kiwi ditentukan dengan menjumlahkan volume dari masing-masing segmen atau cacahan.

$$
\begin{aligned}
& A_{i}=\pi\left(\frac{\Delta y}{2}\right)^{2} \\
& V_{i}=\pi\left(\frac{\Delta y}{2}\right)^{2} \Delta x \\
& V_{i}=\pi \int_{a}^{b} f(x)^{2} d x
\end{aligned}
$$

Parameter a, b dan c merupakan parameter yang digunakan untuk menentukan volume buah kiwi dalam algoritma yang telah disusun. Tabel 1 adalah keterangan masing-masing parameter tersebut.

Tabel 1. Parameter penentuan volume buah kiwi [12], [13]

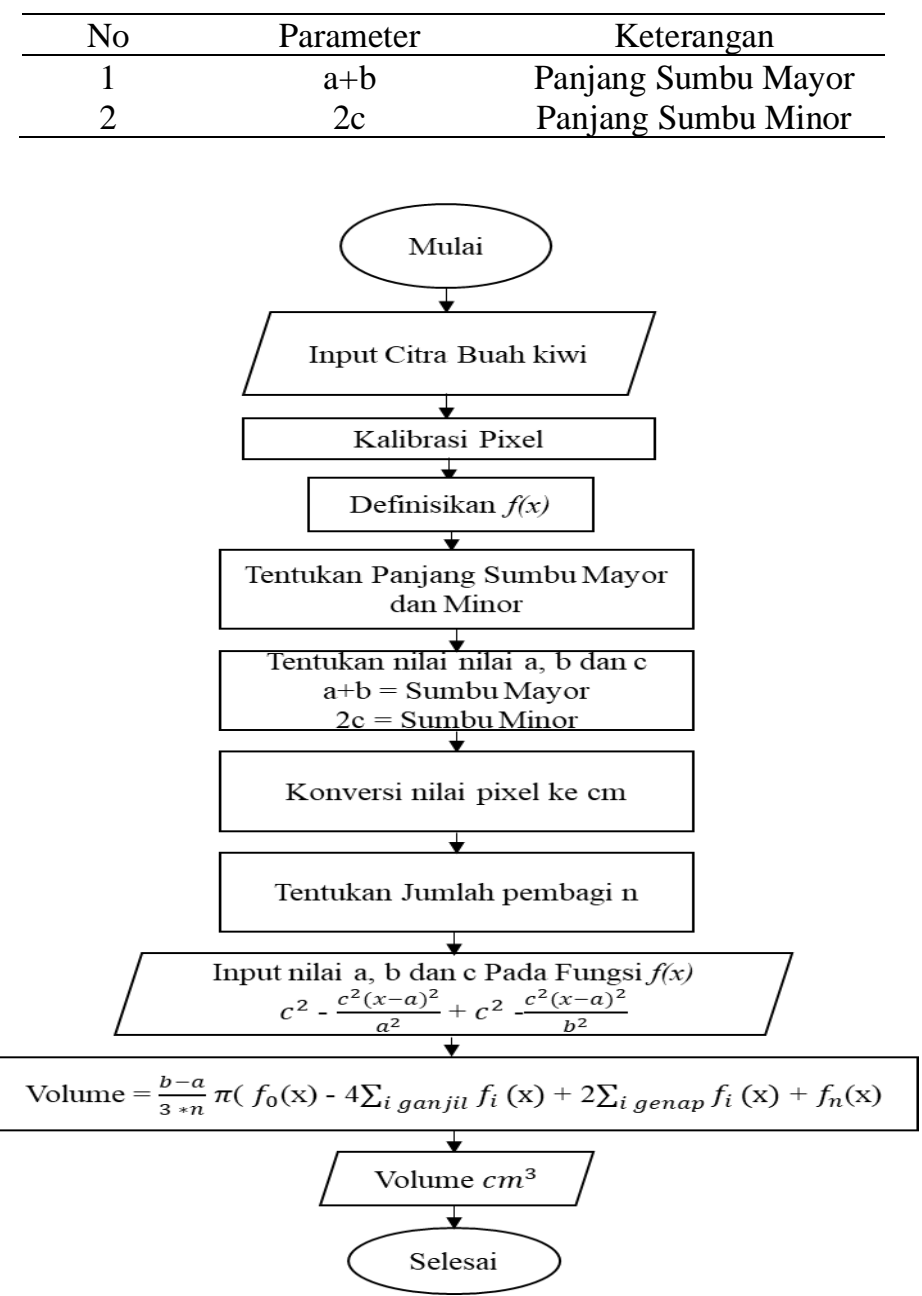

Gambar 4. Algoritma penentuan volume buah kiwi.

\section{HASIL DAN PEMBAHASAN}

\subsection{Hasil Estimasi Volume Buah Kiwi}

Estimasi volume buah kiwi menggunakan metode Computer Vision dengan aturan Simpson 1/3 ditentukan berdasarkan prinsip integrasi volume benda putar. Volume buah kiwi diperoleh melalui penjumlahan volume dari delapan bagian cacahan citra 2D permukaan sampel buah kiwi. Gambar 5 adalah hasil dari pengukuran volume untuk 20 sampel buah kiwi yang diberi kode KH1 sampai KH20. Sampel KH20 mempunyai nilai 
JURNAL MEDIA INFORMATIKA BUDIDARMA

Volume 4, Nomor 3, Juli 2020, Page 535-543

ISSN 2614-5278 (media cetak), ISSN 2548-8368 (media online)

Available Online at https://ejurnal.stmik-budidarma.ac.id/index.php/mib

DOI 10.30865/mib.v4i3.2144

volume terbesar yaitu $126,85 \mathrm{~cm}^{3}$, sedangkan KH13 adalah sampel buah kiwi dengan nilai volume terkecil yaitu $82,48 \mathrm{~cm}^{3}$.

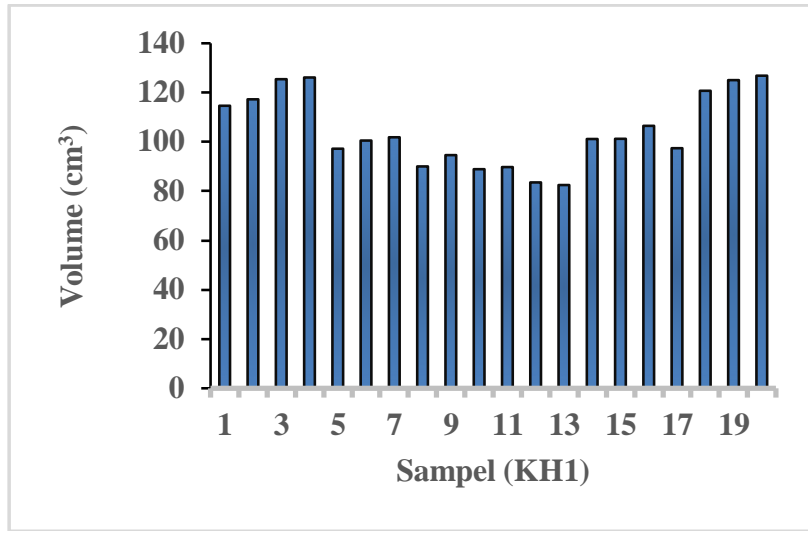

Gambar 5. Grafik volume buah kiwi menggunakan metode aturan Simpson

\subsection{Komparasi Metode Pengukuran Volume Buah Kiwi}

Estimasi volume buah kiwi mengunakan metode Computer Vision dengan aturan Simpson 1/3 telah berhasil dilakukan untuk 20 sampel buah kiwi. Tabel 2 memperlihatkan hasil pengukuran mengunakan metode pencitraan Computer Vision dengan aturan Simpson 1/3 dan pengukuran dengan metode perpindahan air.

Tabel 2. Volume buah kiwi menggunakan metode aturan Simpson dan metode perpindahan air.

\begin{tabular}{ccccccc}
\hline No & Kode & L1 & D1 & D2 & \multicolumn{2}{c}{ Volume $\left(\mathrm{cm}^{3}\right)$} \\
\cline { 6 - 7 } & Sampel & $(\mathrm{cm})$ & $(\mathrm{cm})$ & $(\mathrm{cm})$ & WDM & SM \\
\hline 1 & KH1 & 6.88 & 5.97 & 5.47 & 119,57 & 114,65 \\
2 & KH2 & 7.07 & 5.76 & 5.50 & 120,86 & 117,26 \\
3 & KH3 & 7.33 & 5.88 & 5.58 & 129,79 & 125,43 \\
4 & KH4 & 7.04 & 6.02 & 5.69 & 131,92 & 126,12 \\
5 & KH5 & 6.63 & 5.25 & 5.38 & 103,83 & 97,22 \\
6 & KH6 & 6.67 & 5.95 & 4.94 & 108,51 & 100,53 \\
7 & KH7 & 6.74 & 5.27 & 5.39 & 104,69 & 101,86 \\
8 & KH8 & 6.79 & 5.29 & 4.87 & 89,13 & 90,03 \\
9 & KH9 & 6.67 & 5.51 & 4.81 & 100 & 94,62 \\
10 & KH10 & 6.45 & 5.30 & 5.16 & 103,41 & 88,91 \\
11 & KH11 & 6.82 & 5.46 & 4.66 & 100,85 & 89,77 \\
12 & KH12 & 6.25 & 5.25 & 5.03 & 82,54 & 83,54 \\
13 & KH13 & 6.64 & 5.23 & 4.49 & 87,02 & 82,48 \\
14 & KH14 & 6.74 & 5.80 & 4.86 & 104,69 & 101,16 \\
15 & KH15 & 7.02 & 5.82 & 4.65 & 109,36 & 101,24 \\
16 & KH16 & 6.98 & 5.88 & 4.94 & 111,92 & 106,50 \\
17 & KH17 & 6.53 & 5.64 & 5.13 & 105,54 & 97,428 \\
18 & KH18 & 6.79 & 6.15 & 5.57 & 120,86 & 120,73 \\
19 & KH19 & 7.11 & 6.10 & 5.52 & 125,53 & 125,05 \\
20 & KH20 & 7.26 & 6.07 & 5.51 & 130,64 & 126,85 \\
\hline
\end{tabular}

Pada Tabel 2, sampel buah kiwi diberi kode KH1 sampai KH20. Mengunakan pendekatan elipsoida [17], panjang (L1), diameter mayor (D1) dan minor (D2) buah kiwi diukur menggunakan jangka sorong digital. Tabel 2 juga memperlihatkan nilai volume menggunakan metode perpindahan air (WDM) dan metode pencitraan Computer Vision dengan aturan Simpson 1/3 (SM). Nilai volume hasil estimasi (SM) yang paling rendah adalah pada KH13 yaitu $82,48 \mathrm{~cm}^{3}$, ini berhubungan dengan nilai diameter mayor (D1) dan minor (D2) yang paling rendah, sementara nilai volume yag paling tinggi adalah pada KH20 yaitu $126,85 \mathrm{~cm}^{3}$ yang berhubungan dengan panjang (L1) yang paling tinggi. Sementara itu nilai volume mengunakan metode perpindahan air (WDM) terendah adalah pada sampel $\mathrm{KH} 12$ yaitu $82,54 \mathrm{~cm}^{3}$ dan paling tinggi pada $\mathrm{KH} 4$ yaitu $131,92 \mathrm{~cm}^{3}$. Namun Volume dengan metode WDM tidak bergantung secara signifikan terhadap nilai panjang (L1), diameter mayor (D1) dan minor (D2).

Perbedaan rata-rata nilai volume 20 sampel buah kiwi menggunakan metode WDM dan metode SM adalah $d=4,97 \mathrm{~cm}^{3}$ dan persentase perbedaan rata-rata nya adalah 4,57\% lebih kecil dibanding yang diperoleh oleh Rashidi dkk [17] yaitu 7,8 \%. Standar deviasi perbedaan antara nilai volume yang diperoleh menggunakan WDM dan SM adalah $S_{d}=3,87$. Data perbedaan nilai volume yang diperoleh kedua metode ini terdistribusi 
JURNAL MEDIA INFORMATIKA BUDIDARMA

Volume 4, Nomor 3, Juli 2020, Page 535-543

ISSN 2614-5278 (media cetak), ISSN 2548-8368 (media online)

Available Online at https://ejurnal.stmik-budidarma.ac.id/index.php/mib DOI 10.30865/mib.v4i3.2144

secara normal dan $95 \%$ perbedaan nilai volume diperkirakan berada diantara $d-1,96 S_{d}$ dan $d+1,96 S_{d}$, yang disebut dengan ketentuan batas rentang untuk 95\% sebaran data perbedaan yang terdistribusi secara normal. Jika nilai volume hasil WDM dianggap sebagai standar yang umum maka kesalahan relatif metode SM untuk nilai volume tertinggi dan terendah masing-masing $0,07 \%$ dan $3,84 \%$.

Gambar 6 adalah grafik hubungan antara nilai volume dari 20 sampel buah kiwi yang ditentukan menggunakan metode pencitraan Computer Visioon dengan aturan Simpson (SM) dan metode perpindahan air (WDM). Dari Gambar 6, dapat dilihat bahwa korelasi antara keduanya sangat signifikan dengan nilai $\mathrm{R}^{2}$ sebesar 0,93 yang diperoleh mengunakan analisa regresi sigmaplot.

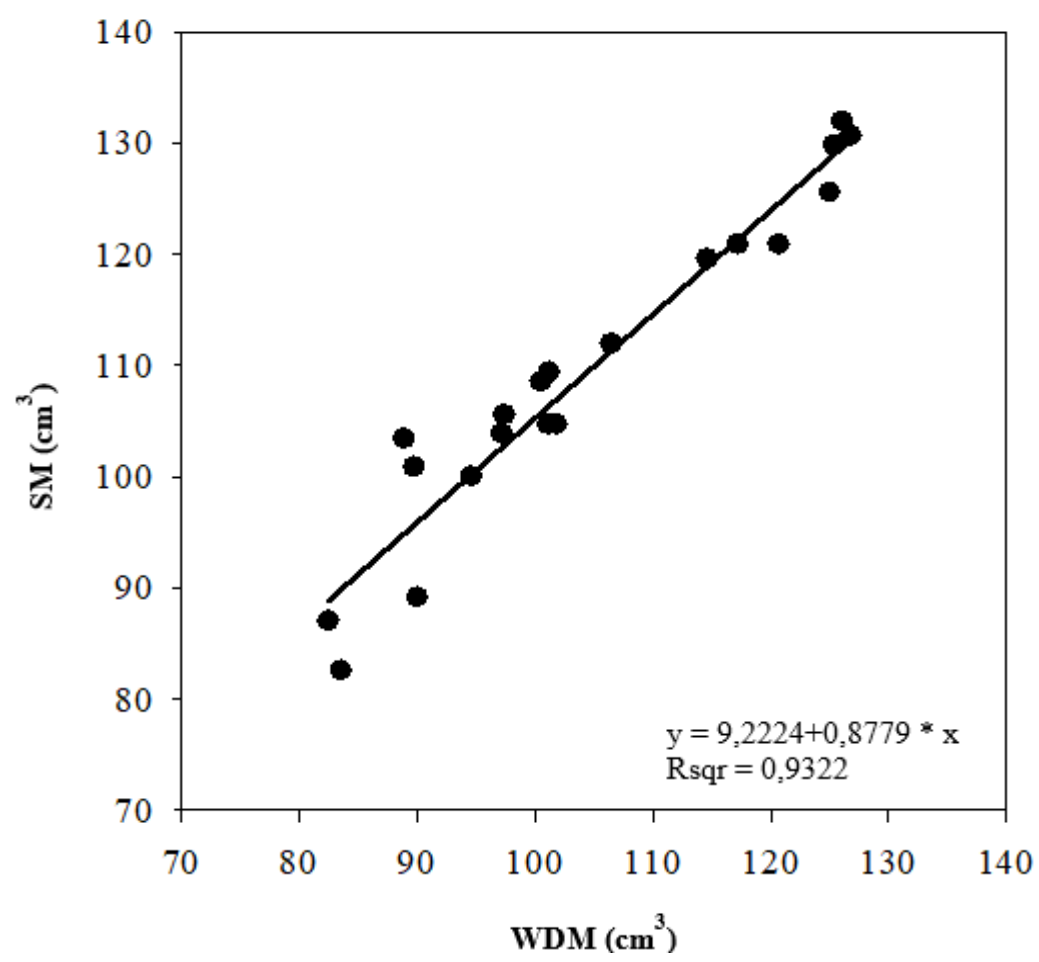

Gambar 6. Grafik hubungan antara nilai volume buah kiwi yang diukur menggunakan metode Pencitraan dengan aturan Simpson (SM) dan metode perpindahan air (WDM)

Hasil penelitian mengunakan metode pencitraan Computer Vision dengan aturan Simpson (SM) dan metode perpindahan air (WDM) yang telah dilakukan masing masing berkisar antara $82,48 \mathrm{~cm}^{3}-126,85 \mathrm{~cm}^{3}$ dan $82,54 \mathrm{~cm}^{3}-131,92 \mathrm{~cm}^{3}$. Hasil ini tidak jauh berbeda dari hasil penelitian-penelitian sebelumnya seperti yang telah dilakukan oleh Rashidi dkk [17] dengan membandingkan penentuan volume mengunakan pendekatan elipsoida melalui pengukuran panjang sumbu mayor dan minor secara manual, melalui pemrosesan citra 2D dan dibandingkan dengan penentuan volume mengunakan metode perpindahaan air.

Hasil estimasi Rashidi dkk [17] menghasilkan nilai volume buah kiwi berkisar dari $54,7 \mathrm{~cm}^{3}-108,3$ untuk WDM dan 45,4 $\mathrm{cm}^{3}$ - 126, 2 untuk IPM (Image Processing Method) dengan interval Confidence sebesar $90 \%$. Volume buah kiwi juga telah diestimasi mengunakan pengukuran panjang, pengukuran diameter mayor dan diameter minor buah kiwi [18] sebagai parameter tambahan di alat sortir buah kiwi. Volume meskipun belum distandarisasi untuk buah, merupakan besaran yang penting dalam manajemen pendistribusian khususnya untuk penyimpanan, pengemasan, transportasi dan pemasaran. Hasil estimasi volume menunjukkan nilai ratarata dari 490 sampel adalah 93,9 $\mathrm{cm}^{3}$. Estimasi volume juga dilakukan mengunakan rekonstruksi 3D dari tiga citra dari tiga sisi berbeda [19]. Hasil Xu dkk [19] menunjukkan bahwa akurasi grading buah kiwi mencapai 97,73 \% dengan memasukkan parameter volume dalam algoritma keputusannya. Razavi dan Bahramparvar [16] juga telah mengukur berbagai sifat fisika buah kiwi salah satunya adalah volume. Volume hasil pengukuran secara destruktif berkisar antara $85-120 \mathrm{~cm}^{3}$ (true volume) dan 63,69-109,01 cm (Appararent volume). 


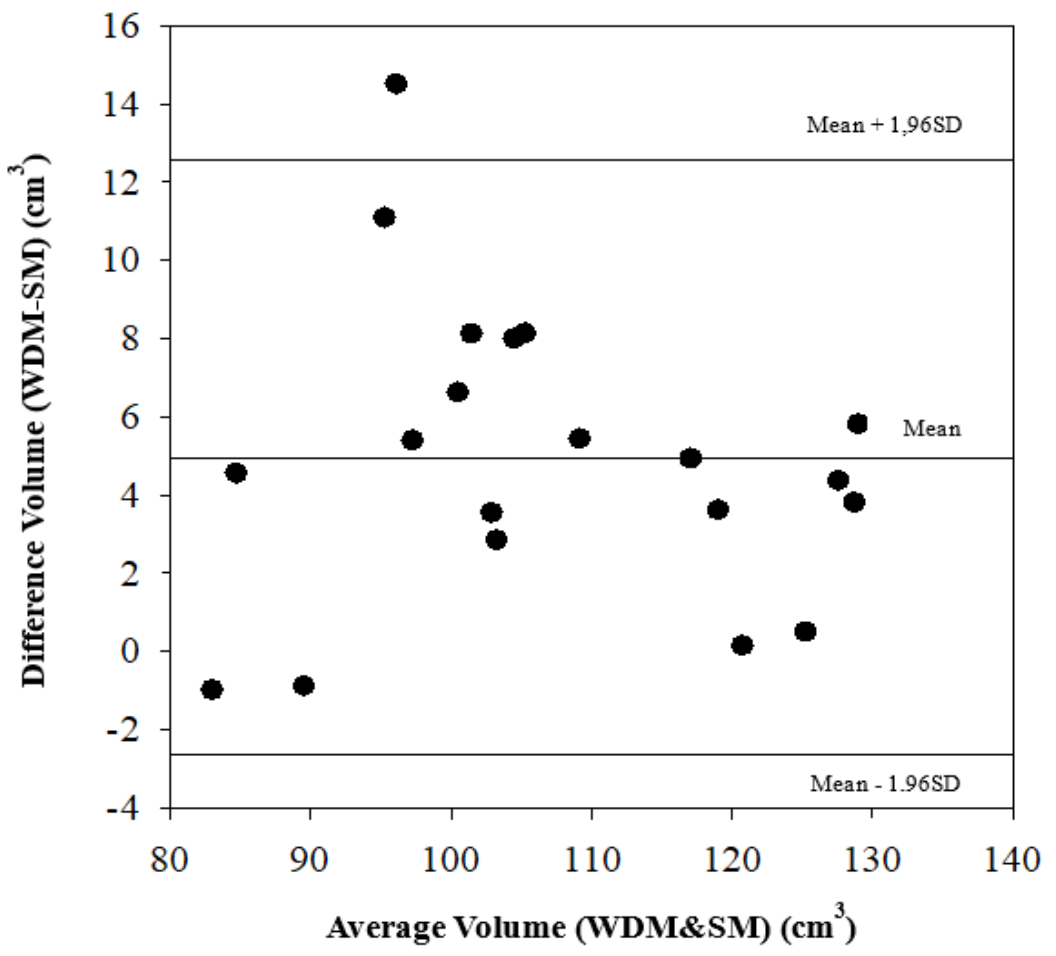

Gambar 7. Plot Bland-Altman untuk komparasi dua metode pengukuran volume buah kiwi.

Nilai volume dari 20 sampel buah kiwi yang diukur menggunakan metode perpindahan air (WDM) dan metode pencitraan Computer Vision dengan aturan Simpson (SM) yang telah diukur tidak jauh berbeda dengan hasil dari peneliti sebelumnya khususnya Rashidi dkk [17], Razavi dan Bahramparvar [16], dan Fu dkk [18]. Plot Blant-Altman juga dapat digunakan untuk mengevaluasi hasil pengukuran mengunakan metode (SM) seperti yang diperlihatkan oleh Gambar 7. Hasil penelitian memperlihatkan perbedaan pada rentang nilai $d-1,96 S_{d}$ sampai $d+1,96 S_{d}\left(-2,62\right.$ dan $\left.12,56 \mathrm{~cm}^{3}\right)$. Nilai volume sampel buah kiwi yang dihitung $2,62 \mathrm{~cm}^{3}$ lebih rendah atau $12,56 \mathrm{~cm}^{3}$ lebih tinggi dari nilai volume yang diperoleh menggunakan metode perpindahan air (WDM). Hasil ini lebih baik karena mempunyai rentang yang lebih kecil dibanding yang diperoleh oleh Rashid dkk [17] yaitu berkisar antara -18,10 dan 13,64 $\mathrm{cm}^{3}$. Gambar 7 memperlihatkan bahwa ada dua nilai volume pada buah kiwi yang kecil dimana estimasi mengunakan metode SM lebih besar dibanding dengan WDM (WDM-SM $<0$ ), namun secara keseluruhan nilai volume dengan SM lebih kecil dari WDM (WDM-SM > 0). Perbedaan ini dapat disebabkan karena keakuratan metode Simpson dengan pendekatan elipsoida yang telah digunakan untuk menentukan volume buah kiwi. Sampel buah kiwi yang digunakan tidak sepenuhnya berbentuk persis elipsoida [17] tidak seperti hal telurnya atau lambung kapal yang dapat didekati dengan bentuk elipsoida [12], [13]. Namun metode pencitraan dengan Computer Vision telah dapat digunakan untuk menentukan volume buah kiwi secara nondestruktif sebagai alternatif mengantikan metode perpindahan air sehingga dapat digunakan dalam proses penyortiran buah mengunakan parameter volume.

\section{KESIMPULAN}

Estimasi volume buah kiwi (Actinidia deliciosa) sebanyak 20 buah mengunakan metode pencitraan Computer Vision telah behasil dilakukan. Algoritma penentuam volume yang digunakan adalah aturan Simpson 1/3 (SM). Perekaman citra dan pengolahan citra dan penentuan volume dilakukan mengunakan program berbasis Python. Hasil tersebut dibandingkan dengan metode tradisional mengunakan Hukum Archimedes atau metode perpindahan air (WDM). Nilai volume yang diperoleh mengunakan metode SM berkisar antara 82,48 - 126,85 $\mathrm{cm}^{3}$, sementara mengunakan (WDM) nilai volume berkisar antara 82,54-131, $92 \mathrm{~cm}^{3}$. Perbedaan rata-rata antara kedua metode adalah $4,97 \mathrm{~cm}^{3}$ atau sebesar $4,57 \%$. Nilai volume hasil estimasi (SM) yang paling rendah adalah pada KH13 yaitu $82,48 \mathrm{~cm}^{3}$, ini berhubungan dengan nilai diamter mayor (D1) dan minor (D2) yang paling rendah, sementara nilai volume yag paling tinggi adalah pada KH20 yaitu $126,85 \mathrm{~cm}^{3}$ yang berhubungan dengan panjang (L1) yang paling tinggi. Hasil dari analisa mengunakan Plot Blant memperlihatkan perbedaan pada rentang nilai $-2,62$ dan $12,56 \mathrm{~cm}^{3}$. Hasil tersebut juga memperlihatkan bahwa ada dua nilai volume pada buah kiwi yang kecil dimana estimasi mengunakan metode SM lebih besar dibanding dengan WDM (WDM-SM < 0), namun secara keseluruhan nilai volume dengan SM lebih kecil dari WDM (WDM-SM > 0). Perbedaan antara kedua metode dapat disebabkan karena pendekatan elipsoida untuk bentuk buah kiwi, dimana bentuk buah kiwi yang sebenarnya bervariasi dari hampir bulat dan elips namun tidak persis 
JURNAL MEDIA INFORMATIKA BUDIDARMA

Volume 4, Nomor 3, Juli 2020, Page 535-543

ISSN 2614-5278 (media cetak), ISSN 2548-8368 (media online)

Available Online at https://ejurnal.stmik-budidarma.ac.id/index.php/mib

DOI 10.30865/mib.v4i3.2144

seperti bentuk elips telur. Disamping itu pada penelitian ini megunakan integrasi dengan aturan Simpson 1/3 saja, metode integrasi lainnya seperti aturan Simpson 3/8 atau gabungan keduanya adalah hal yang perlu diekplorasi kedepannya.

\section{UCAPAN TERIMAKASIH}

Penelitian ini di dukung oleh Universitas Riau dan merupakan bagian dari penelitian yang dibiayai DRPM (Penelitian Dasar 2018/2019). Ucapan Terimakasih Kepada Ikhsan Rahman Husein dan Ramma Hayu Fitra yang telah membantu dalam penguasaan program Python dan pengolahan citra.

\section{REFERENCES}

[1] R. Mahendran, G.C. Jayashree, and K. Alagusundaram, "Application of Computer Vision Technique on Sorting and Grading of Fruits and Vegetables," J. Food Process. Technol S1-001, 2012, doi:10.4172/2157-7110.S1-001

[2] W. R. Ashok, M. S. Panse, and H. Apte, "Laser Triangulation Based Object Height Measurement," International Journal For Research In Emerging Science And Technology, Vol. 2. No.3, 61-66, 2015

[3] H. Wang, J. Peng, C. Xie, Y. Bao, and Y. He, "Fruit quality evaluation using spectroscopy technology: A review," Sensors (Basel). Vol 15. No.5. 11889-11927 2015, doi: 10.3390/s150511889

[4] J. A. Kodagali and S. Balaji, "Computer Vision and Image Analysis based Techniques for Automatic Characterization of Fruits a Review,” Int. J. Comput. Appl., Vol. 50. No. 6. 6-12. 2012, doi: 10.5120/7773-0856.

[5] G. Rateni, P. Dario, and F. Cavallo, "Smartphone-based food diagnostic technologies: A review," Sensors (Switzerland). Vol. 17. 1453. 2017, doi: 10.3390/s17061453.

[6] S. Jatmika and D. Purnamasari, "Rancang Bangun Alat Pendeteksi Kematangan Buah Apel Dengan Menggunakan Metode Image Processing Berdasarkan Komposisi Warna," J. Ilm. Teknol. Inf. Asia, Vol. 8. No.1. 2014.

[7] P. Zhou, C. Zhao, J. Wang, W. Zheng, Z. Sun, and Y. Wen, "Egg geometry calculations based on machine vision," Nongye Jixie Xuebao/Transactions Chinese Soc. Agric. Mach., 2010, doi: 10.3969/j.issn.1000-1298.2010.05.034.

[8] M. A. Momin, M. T. Rahman, M. S. Sultana, C. Igathinathane, A. T. M. Ziauddin, and T. E. Grift, "Geometry-based mass grading of mango fruits using image processing," Inf. Process. Agric., vol. 4, No. 2, pp. 150-160, 2017, doi: 10.1016/j.inpa.2017.03.003.

[9] R. Fellegari and H. Navid, "Determining the orange volume using image processing," Vol. 9, pp. 180-184, 2011.

[10] M. Omid, M. Khojastehnazhand, and A. Tabatabaeefar, "Estimating volume and mass of citrus fruits by image processing technique,” J. Food Eng., Vol 100. No. 2. 315-321. 2010.

[11] N. Herfina, A. Amrullah, and J. Junaidi, "Efektivitas Metode Trapesium dan Simpson Dalam Penentuan Luas Menggunakan Pemrograman Pascal," Mandalika Math. Educ. J., Vol 1.No 1. 53-63. 2019, doi: 10.29303/jm.v1i1.1242.

[12] J. Siswantoro, M. Y. Hilman, and M. Widiasri, "Computer vision system for egg volume prediction using backpropagation neural network," in IOP Conference Series: Materials Science and Engineering, 2017, doi: $10.1088 / 1757-899 X / 245 / 1 / 012002$

[13] .N. Made, R. Ratih, and C. Perbani, "Penerapan Hitungan Volume Metode Simpson untuk Menghitung Volume Kapal dan Topografi Darat," Jurnal Rekayasa Hijau Vol. 2, No. 1. 90-100, 2018.

[14] K. V Shastri, V. Bhatia, P. R. Parikh, and V. N. Chaphekar, “Actinidia Deliciosa : A Review,” J. Pharm. Sci. Res., Vol. 3, No. 10, 3543-3549, 2012.

[15] J. Burdon, D. Mcleod, N. Lallu, J. Gamble, M. Petley, and A. Gunson, “Consumer evaluation of ' Hayward ' kiwifruit of different at-harvest dry matter contents," Postharvest Biol. Technol., vol. 3, pp. 245-255, 2013.

[16] S. M. A. Razavi and M. Bahramparvar, "Some physical and mechanical properties of kiwifruit," Int. J. Food Eng., Vol. 3, No. 6. 2007, doi: 10.2202/1556-3758.1276.

[17] M. Rashidi and M. Gholami, "Determination of kiwifruit volume using ellipsoid approximation and image-processing methods," Int. J. Agric. Biol., Vol 10. No. 4, 375-380 2008

[18] L. Fu, S. Sun, R. Li, and S. Wang, "Classification of kiwifruit grades based on fruit shape using a single camera," Sensors (Switzerland), Vol 16. No. 7. 2016, doi: 10.3390/s16071012.

[19] L. Xu, Y. Feng, Z. Fan, and D. Yun, "Research into the grading method of kiwi fruit based on volume estimation and surface defect," INMATEH - Agric. Eng., Vol. 44. No. 3. 2014. 